DOI https://doi.org/10.18551/rjoas.2017-12.28

\title{
HOUSEHOLD CONSUMPTION BEHAVIOR IN TERNATE, INDONESIA
}

\author{
Sun'an Muammil*, Husen Amran \\ Faculty of Economics Khairun, University of Ternate, Indonesia \\ *E-mail: amilsunan78@gmail.com
}

\begin{abstract}
This study aims to analyze the influence of lifestyle, age, size of household, environment, and income on household consumption behavior; test the suitability or deviation from the existing economic theories; select existing regional macroeconomic policies. The study involves families in Ternate City of North Maluku Province. The data analysis is done using a multiple linear regression model. The results show that lifestyle, age, size of household, environment, and income have an effect on household consumption behavior. However, lifestyle, age, and environment have a negative effect on household consumption. This indicates that families in Ternate City want to arrange or make an inter-time choice to consumption in the future. In addition, these lifestyle changes have implications for changes in taste, habits, and purchasing behavior (consumption patterns).
\end{abstract}

\section{KEY WORDS}

Household consumption, lifestyle, age, household size, environment, income.

Household consumption is one of the economic activities to meet various needs of goods and services. Of the commodities consumed, families will gain their satisfaction. Therefore, consumption is often used as one indicator of family welfare. The greater the spending on the consumption of goods and services, the higher the welfare stage of the family (Akmal, 2003).

The Keynesian theory of consumption states that household consumption (C) is positively related to current income-the bigger the income it has, the more the tendency to consume. Keynes also believes high-income households consume less of their income than low-income households do (Case \& Fair, 1999). One important finding in Keynes's economic theory is the tendency to consume that highlights the relationship between additional consumption and additional income. When income increases, consumption also rises, but this increase is not as much as an increase in income.

Meanwhile, according to Duesenberry (Mankiw, 2003), in his relative income hypothesis there is always a tendency of every member of the community to increase their consumption so there is an increase in income. However, consumption is not influenced solely by absolute or relative levels of income at any given time, but also by historical factors and previous levels of consumption. People always reach the standard of consumption to the highest level of income ever achieved. If the relative income is declining, one will not immediately sacrifice the standard of consumption. Therefore, here is a ratchet effect, that is, consumers adjust their consumption slightly due to the decrease in their present income. However, such adjustments are not symmetry because when their relative income increases, they will soon increase consumption to the highest-level ever-achieved (Metwally, 1995).

Under adverse economic conditions, consumption will tend to lag behind by rising income levels, while in times of economic decline, consumption levels will not fall as fast as income growth rates fall. The permanent-income hypothesis states that consumption depends on one's expectations. The rational-expectation assumption dictates that people use all available information to make optimal predictions about the future. At some point, consumers choose based on the present expectations of their income. Changes in consumption reflect a 'shock' to lifetime income (Krisnawati et al., 2004).

This study has a specific purpose to formulate a model of household consumption. Modeling is made to assist in the selection and/or proper local macroeconomic policymaking, and so, economic stabilization can be created. The purposes of this study are (1) to analyze 
the influence of lifestyle, age, household size, environment, and income on household consumption behavior; (b) test suitability or deviation from the existing economic theory; (c) to select existing regional macroeconomic policies.

\section{THEORETICAL REVIEW}

John Maynard Keynes Consumption Theory. The Keynesian theory states that consumption now depends on present income, following this consumption function:

$$
\mathrm{C}_{\mathrm{t}}=\mathrm{C}_{0}+\mathrm{C}_{1} \mathrm{Y}_{\mathrm{t}}
$$

Where: $C_{t}$ is current consumption, $Y_{t}$ is current income, $C_{0}$ is autonomous consumption, and $\mathrm{C}_{1}$ is the marginal propensity to consume (MPC). The above consumption functions can be illustrated in the following figure.

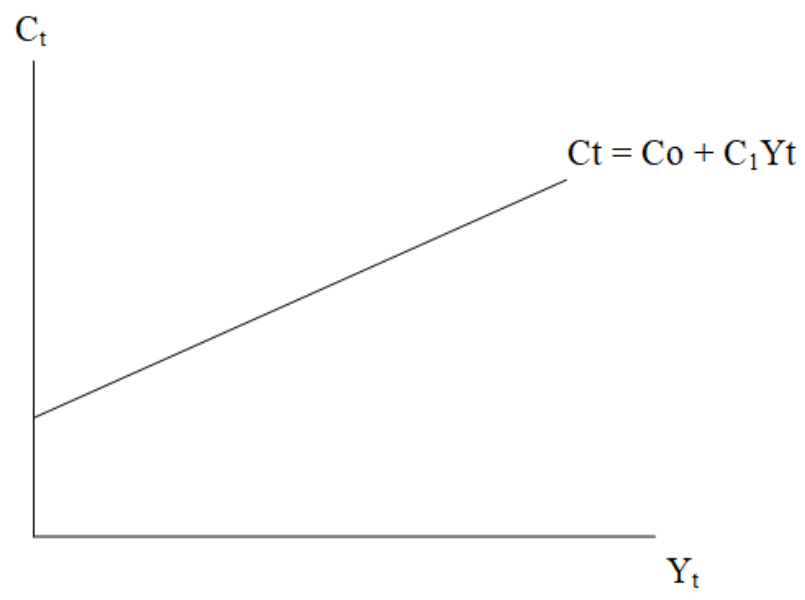

Figure 1 - The relationship between consumption and income

From the above function and figure, it can be seen that (a) MPC is constant and always smaller than average propensity to consume (APC) and (b) APC is decreasing with increasing income. Furthermore, Keynes adds that the relationship is relatively stable and higher nominal income will result in greater proportion for savings.

Consumption Theory with the Life Cycle Hypothesis. According to the Fisher model, consumption depends on a person's lifetime income. Modigliani emphasizes that income varies systematically during one's life and savings enables consumers to use income from the time when it is high to a time when income is low. The life cycle hypothesis assumes that people save to smooth their consumption for life. One important goal is to earn sufficient retirement income. Therefore, people tend to save while working to add deposits to retirement and then spend their savings accumulated in their old age (Samuelson \& Nordhaus, 2004).

Mankiw (1997), Metwally (1995), Soediyono (1995), Branson and William (1972), Wijaya in Suprayitno (2005) state that Franco Modligiani and his collaborators, Albert Ando and Richard Brumberg, use consumer behavior models to study consumption functions. One of their goals is to solve the consumption puzzle, explaining the existence of conflicting evidence when Keynesian consumption is included in the data. According to the Fisher model, consumption depends on the income of one's life. Modigliani emphasizes that income varies systematically during one's life and savings enables consumers to use income from the time when it is high to a time when income is low. Consumption at time t does not follow the amount of income at time $t$ as the Keynesian theory, but follows the long-term income pattern formulated as cash income at time t. The implication is that APC in a life cycle differs from each other - APC is high in early life and old age and is low during the productive age; in other words, APC is inversely proportional to the amount of income. 
Consumption Theory with Relative Revenue Hypothesis. According to Duesenberry, in his theory of relative income hypothesis, there is always a tendency of every member of society to increase consumption so there is an increase in income. Fluctuations in income levels cause consumer behavior (households) to be different in the short and long term. This is because they are essentially not paying much attention to their absolute level of consumption, as is their relative consumption to members of the community surrounding their neighborhood. If consumers always see the household consumption pattern of their richer neighbors, then there is a demonstration effect, but the imitation of the neighbor's consumption pattern is to the surrounding community.

Consumption is not solely influenced by absolute or relative levels of income at any given time, but also by historical factors and previous levels of consumption. Therefore, if income is lower than what one receives now, the person will find it difficult to change their level of consumption to the lower standard. If they even lower their consumption, it is only a small one in reaction to the decline in income. Conversely, there is always a tendency to adjust the pattern and level of consumption to the level of income that already exists. If there is an increase in income, they will try to increase their consumption. The adjustment of the level and pattern due to the increase in income depends on average propensity to consume, which is further expressed as the pattern and the level of long-term consumption (Kimin, 2002).

Consumption Theory with the Permanent Income Hypothesis. Friedman's permanentincome hypothesis complements Modigliani's life cycle hypothesis as both use the consumption theory of Irving Fisher to argue that consumption should not depend solely on current income. But unlike the life-cycle hypothesis, which emphasizes that income follows a regular pattern over a person's lifetime, the permanent-income hypothesis emphasizes that humans experience random and temporary changes in their income from year to year (Mankiw, 2003).

According to this theory, people's income is divided into two, i.e. the permanent income referring to the income received at any given period and the transitory income referring to the unexpected additional or reduction of income (Dornbusch \& Fisher, 1987).

This Friedman theory, like the life cycle hypothesis, also argues that household consumption is primarily determined by long-term income. Friedman defines permanent income as the average long-term income expected to be received from human and nonhuman wealth. Income from human wealth is income received from providing human skills, and as the reward, they will earn salary, wages, and other remuneration from work. Non-human wealth includes income is derived from property and fixed assets such as income from stock ownership, bonds, and real estate. If the permanent income hypothesis is true and the consumer has rational expectations, then the consumption change may be unexpected and this change is known as the random walk. The reasons given are as follows: if this hypothesis is true, then consumers will follow the fluctuations in income by trying to reduce the fluctuations in consumption, yet still with the expectation that income level will change the level of consumption.

\section{METHODS OF RESEARCH}

Design of the Study. This study is a combination of quantitative and explanatory research. Quantitative research involves testing the hypothesis or the relationship between research variables through the processing of quantitative data. Explanatory research is a study involving hypothesis testing. Such research also contains descriptions, but the focus lies in the analysis of relationships between variables (Hadari, 1998).

Data Collection Technique. The main data used is primary data. Secondary data is to support the primary data. Primary data is collected through questionnaires distribution method to selected respondents.

One way to determine the size of the sample to be used as a data source is by estimating the proportion of the number of objects that have certain characteristics in a population. 
To obtain a minimum sample that must be investigated, the following formula (Nawawi, 1983) is used:

$$
\mathrm{n} \geq \mathrm{pq}\left(\frac{z_{1 / 2} \alpha}{b}\right)^{2}
$$

In which:

$\mathrm{n}=$ the minimum sample size;

$\geq=$ equal to or greater;

$\mathrm{p}=$ percentage of the population proportion of the first group;

$q=$ residual proportion in population $(1-p)$;

$Z_{1 / 2}=$ the degree of coefficient confidence at $99 \%$ or $95 \%$;

$\mathrm{b}=$ the estimated probability (in percentage) of making a mistake in determining sample size.

After determining the minimum number of sample, the next step is sampling through a purposive sampling technique.

Data analysis method. Consumption function in this study is as follows:

$$
\mathrm{Ci}=\mathrm{f}(\text { Lifestyle, Age, Size, Environment, Income })
$$

The general consumption function above will be converted into a multiple linear regression form, as follows:

$$
C i=\beta_{0}+\beta_{1} \text { Style }+\beta_{2} \text { Usia }+\beta_{3} \text { Size }+\beta_{4} \text { Lingk }+\beta_{5} \text { Income }+\varepsilon t
$$

In which:

$\mathrm{Ci}$ : the pattern of household consumption;

$\beta i$ : regression coefficient of independent variables;

$\beta_{0}$ : constants;

Style: lifestyle;

Age: age of household head;

Size: household size;

Environ: environment;

Income: income;

عt: error term.

\section{RESULTS AND DISCUSSION}

The result of data analysis shows that lifestyle, household size, environment, and income have significant effect to consumption level at $5 \%$ error level. Age variable has no significant effect on the level of consumption. Thus, the consumption level in North Maluku Province is influenced by lifestyle, household size, environment, and income.

\begin{tabular}{|c|c|c|c|c|}
\hline Variable & Coefficient & Std. Error & t-Statistic & Prob. \\
\hline Style & -2.499 & 0.666073 & -3.751484 & 0.0002 \\
\hline Age & -0.018 & 0.154287 & -0.114446 & 0.9090 \\
\hline Size & 1.199 & 0.622659 & 1.926115 & 0.0551 \\
\hline Environment & -2.727 & 1.4195507 & -1.921313 & 0.0557 \\
\hline Income & 25.386 & 2.283910 & 11.11505 & 0.0000 \\
\hline Constant & -3.734 & $1.06 \mathrm{E}+08$ & -3.506144 & 0.0005 \\
\hline R-square & 0.5964 & \multicolumn{2}{|c|}{ F-statistic } & 50.24133 \\
\hline Adjusted R-square & 0.5845 & \multicolumn{2}{|c|}{ Prob (F-statistic) } & 0.000000 \\
\hline Durbin-Watson stat & 2.350985 & \multicolumn{3}{|c|}{-} \\
\hline
\end{tabular}

$C i=-3.734-2.499$ Lifestyle -0.018 Age +1.199 Size -2.727 Environment +25.386 Income $+\varepsilon t$

Table 1 - The Result of Linear Regression Test of Household Consumption 
Lifestyle. Lifestyle reflects the values adopted by society itself. Consumption of an item, according to Weber (in Damsar, 2002), is a description of a particular lifestyle of a particular status group. Consumption of goods is the basic for the inclusion of status groups. Thus, it differs from the class whose basic is the relationship to production and the acquisition of goods. Lifestyle gives an explanation that a person sometimes consumes certain goods simply for showing off which usually always include elements of admiration. The Veblen effect shows that the usefulness derived from consuming goods for showing off depends on two things, namely quality and price.

Based on the results of the study, lifestyle affects the pattern of household consumption. However, there is a negative relationship between lifestyle and household consumption patterns in Ternate City, as luxury lifestyle will reduce the proportion of spending for food. It implies that the lifestyle of every household will cause a shift in consumption patterns. Households will reduce expenses for food in order to meet the needs of luxury goods.

In this study, the type of work, the shopping habits, and the dresses worn represents the household lifestyle. They are indicators used to differentiate a person's or a household's social status that can directly influence lifestyle or behavior. Lifestyle gives an explanation that a person sometimes consumes certain goods simply for showing off which usually always include elements of admiration. It is understandable that the goods for a person are no longer merely to meet the need for life but also for enjoyment and prestige.

Household Size. The size of the households referred to in this study is the number of household members in one family, consisting of husband, wife, and children (including relatives) who are the burden or dependents of the household head in the fulfillment of daily needs. Thus, it can be concluded that the more household members, the higher the necessity of life, especially for daily consumption. According to demand theory, the higher the population (household), the higher the demand for goods and services will be. It is understandable that more household members will increase demand for goods and services. Thus, the number of household members will affect the consumption pattern of the household. However, the changes occurring in household consumption are more likely to food.

The results of the study show that the size of households significantly influences the pattern of household consumption in Ternate, with a positive relationship between household size and consumption patterns. This implies that the larger the size of the household will bring a rise in household spending or a larger shift from non-food consumption to food consumption. In other words, the number of household members makes household spending for goods, other than food, to change (decrease) to replace food items. This is also in line with Angeletos et al. (2001) which state that consumption reaches its peak in the middle of life, as the number of children increases. This means more children causes a drastic increase in the household needs for consumption of goods and services (especially food). Similarly, Eilenstene and Cunningham (1972), in their research entitled "Projected Consumption Patterns for a Stationary Population" conclude that age and household size variables influence consumer spending in the opposite way. However, the results of this study indicate that the size of households is positively related to the pattern of household consumption in Ternate City.

Environment. Interaction with the environment explains the adjustment of families to change by comparing the contemporary behavior of families in different environments and steady consumption patterns over time. It means that different environment makes household to adjust itself, which can change its consumption pattern (Wallis, 1942). This is consistent with the consumption theory of the relative income hypothesis, which states that essentially a person or household is not so concerned with their absolute level of consumption, as is with its relative consumption of the members of society around its environment.

The results of this study indicate that environmental factors significantly influence the pattern of household consumption in Ternate. However, there is a negative relationship between environmental factors and household consumption patterns. This means that the 
better the interaction of the head of household with the environment or the community around, then most likely there is a change (decrease) in food consumption. It also provides an interpretation that improved interaction between households and the surrounding community will cause a change in consumption patterns. This will lead to a demonstration effect in which households will adapt or follow the consumption patterns of their neighbors or friends. Thus, households will make choices by reducing the consumption of food, as to consume non-food items such as the purchase of mobile phones, credits, recreation, or entertainment, and so on. This is in line with Wallis's (1942) research entitled "The Temporal Stability of Consumption Patterns", indicating that the validity of estimated consumption depends on how families adjust to change by comparing the contemporary behavior of families in different environments, and steady consumption patterns over time. Likewise, the research by Sun and Wu (2004) entitled "Consumption Patterns of Chinese Urban and Rural Consumers" confirm that Chinese people who attain a certain standard of living develop a need for quality of life, requiring the fulfillment of social needs and self-symbolic consumption. When rural consumers adopt the consumption pattern of urban consumers, the objects that become luxury goods then become necessities.

Age. Changes in one's age will affect or change the consumption pattern of goods and services. Age causes consumers to smooth the level of consumption over time. It indicates a household's expectation of the conditions to come, by managing the current consumption. Thus, it can be concluded that households make inter-temporal choice. When a person decides how much income will be consumed and how much is saved, one considers the present and future conditions. The more one consumes today, the less one can consume in the future. Kelly and Lanot (2002) build a theoretical framework to characterize the optimum behavior of individuals who receive income periodically but make consumption decisions more regularly. The results explain how individuals allocate consumption optimally to different periods of their lives based on available information about lifelong resources.

The results of the study show that the age of household head does not significantly influence the pattern of household consumption in Ternate City. That is, consuming or purchasing decisions is not based on head's age, but only on the current needs. The results of this study also indicate that there is a negative relationship between the age of head of household with the pattern of consumption. This implies that the older the person, the lower their consumption of the non-food items. In other words, households rationally have the foresight to make different inter-time choices. Similarly, Browning and Crossley (2001), in their research on "The Life-Cycle Model of Consumption and Saving", showing the life cycle framework, states that the agent must make sequential decisions to achieve coherent (and stable) goals by using available information as well as possible. Empirical evidence seems to suggest that parents are dissaving as predicted by the general life cycle model. In addition, Eilenstene and Cunningham (1972) conclude that age affects consumer spending in the opposite way. This means that the older the age of a person or household, the lower the spending for food will be.

Income. The inter-temporal choice theory proposed by Irving Fisher explains that each individual will decide how much income will be used for current consumption and future consumption. The more one consumes today, the less one can consume in the future. In addition, Keynes's consumption theory states that current consumption is dependent on current income. According to Keynes, a minimum threshold does not depend on the level of income-the level of consumption must be met, although the income level is equal to zero, which is called as autonomous consumption. If disposable income increases, consumption will also increase, except that the increase in consumption is not as much as the increase in disposable income (Mankiw, 2003).

The results of the study indicate that income significantly influences to pattern of household consumption in Ternate City. The results also show that there is a positive relationship between household income and consumption patterns. That is, the higher household income will lead to an increase in consumption patterns (food and non-food). This is in line with the study by Kimin (2002), which proves that the increase in income is followed by increased consumption by following short-term consumption patterns. Likewise, the 
results of interviews with 281 households show that 249 households (88.61\%) have consumption patterns influenced by income levels. The high-income make the household to have more choices to the various goods that will be consumed. The increase in income will change patterns of spending.

\section{CONCLUSION AND SUGGESTIONS}

Based on observations and data analysis on the pattern of household consumption in Ternate, then some conclusions can be drawn as follows:

1. A person's lifestyle will affect the decision in buying a certain item. Research results show that lifestyle influences the pattern of household consumption. However, there is a negative relationship between lifestyle and household consumption patterns in Ternate City. This means that the luxury lifestyle of household will reduce the proportion of spending for food.

2. Age of the head of household does not significantly influence the pattern of household consumption in Ternate City. That is, that the head of the household in consuming or purchasing decisions of a good is not based on the age, but only on the current needs of the moment. The results of this study also indicate that there is a negative relationship between the age of head of household with the pattern of consumption. This implies that the older the age of a person or household, the lower the spending for food will be. In other words, households rationally have the foresight to make different time choices.

3. The size of household affects the consumption patterns in Ternate City. The more household members, the higher the necessity of life, especially for daily consumption. Thus, the number of household members will affect the consumption pattern of the household. However, the changes occurring in household consumption are more likely to food.

4. Environmental factors negatively affect household consumption, which means that better interaction with the environment will reduce household consumption of food. Improved interaction between heads of households with neighbors or friends leads to a shift in the consumption of food to non-food items. Thus, strong or high interaction with neighbors causes the household to imitate the neighbors' consumption pattern (demonstration effect).

5. Income level significantly influences the pattern of household consumption in Ternate City. The results indicate that there is a positive or direct relationship between income levels with household consumption patterns. That is, the higher household income will increase in consumption patterns (food and non-food).

Suggestions:

1. Household size and environmental variables affect household consumption patterns. Therefore, with an increasing number of dependents or household size, household heads need to think and work harder to earn extra income to meet the household's demand for food. Thus, every household must be more rational in making choices related to current and future consumption patterns. In addition, government policies are needed to stabilize prices in general, especially food prices. Likewise, households must not follow the lifestyle of the people around them; they should be more rational in deciding the pattern of spending in accordance with the needs and budget owned.

2. Income and household wealth have an effect on household consumption patterns in Ternate City. Thus, it is necessary to have a policy that can maintain price stability, especially basic needs, as this directly affects the level of income and household wealth. In addition, the government needs to create even more jobs for the community, thereby directly increasing the income which then increases the ability to consume goods and services. Complete and correct information about changes in price - price of goods and other policies that can affect consumption patterns household must also be made available. 
3. The results of the study show differences in the pattern of household consumption in Ternate, as the internal factor affecting decision making of each individual is very different. Related parties are expected to find solutions in resolving internal problems that cause differences in consumption. Thus, policies related to employment and decent life for the community must be made.

4. It is necessary to conduct further and more in-depth research on consumption patterns, especially to see specific variables such as the phenomenon of fast food stall mushrooming.

\section{REFERENCES}

1. Akmal. 2003. Analisis Pola Konsumsi Keluarga di Kec. Tallo, Kota Makassar. Tesis Pasca Sarjana Universitas Hassanudin, Makassar.

2. Angeletos, George-Marios; David Laibson; Andrea Reppeto; Jeremy Tobacman; dan Stephen Weinberg. 2001. "The Hyperbolic Consumption Model: Calibration, Simulation, and Empirical Evaluation. Jurnal of Economic Perspectives, Vol. 15, No.3-September. p. 47-68.

Browning, Martin dan Thomas F Crossley. 2001. "The Life-Cycle Model of Consumption and Saving". The Journal of Economic Perspectives, Vol. 15, No. 3. p. 3-22. Published by American Economic Association.

3. Case E. Karl dan Fair C. Ray. 1999. Principles of Macroeconomics, Fifth Edition. Prentice Hall, Inc. New Jersey.

4. Clements, Kenneth W; Yanrui Wu dan Jing Zhang. 2003. Comparing International Consumption Patterns. Economics Program, The University of Western Australia. p. 3-4.

5. Damsar. 2002. Sosiologi Ekonomi. Edisi Revisi. Penerbit PT RajaGrafindo Persada. Jakarta.

6. Dornbusch, Rudiger dan Stanley Fisher. 1987. Macroeconomics. Sixth edition. McGraw Hill, Inc, New York.

7. Eilenstine, Donald dan James $P$ Cunningham. 1972. Projected Consumption Patterns for a Stationary Population. JSTOR, Population Studies, Vol. 26, No. 2, Juli. p. 223-227.

8. Hadari, Nawawi. 1998. Metode Penelitian Bidang Sosial. Gadjah Mada University Press. Jakarta.

9. Herdiyansah, Herdis. 2007. Konsumsi: Pencitraan yang butuh Teologi. http://www.kompas.com/. Jumat, 27 Juli.

10. Kelly, Clare dan Lanot, Gauthier. 2002., Consumption Patterns Over Pay Period. Keele Economics Research Papers, september. No.12. p. 25-27. Keele University, Staffordshire.

11. Kimin, Basir. 2002. Pola Konsumsi Petani Karet Sawah Ditinjau dari Hipotesis Pendapatan Relatif "Studi KasusTiga Desa di Kec. Sirahpulaupadang". Jurnal Ekonomi dan Bisnis Indonesia. Vol. 17, No. 3, hal.277-284. Juli 2002. FE-UGM, Yogyakarta.

12. Krisnawati, Enni; S.M. Kiptiyah dan Harry Susanto. 2004. Analisis Pola Konsumsi Rumah Tangga Nelayan dalam Perspektif Ekonomi dan Sosial (Studi Kasus pada Desa Bandaran Kec. Tlanakan, Kab. Pamekasan). Jurnal TEMA Vol. 5, No.1, hal.72-84. Maret 2004. FE-Unibraw Malang.

13. Mankiw, Gregory N. 1997. Makroeconomics 4th Edition. New York and Basingstoke by Worth Publishers.

14. Mankiw, Gregory N. 2003. Makroeconomics 5th Edition. New York and Basingstoke by Worth Publishers.

15. Metwally, M.M, 1995. Teori dan Model Ekonomi Islam. PT. Bangkit Daya Insana, Edisi Pertama, Jakarta.

16. Sun, Tao dan Wu, Guogua, 2004. Consumption Patterns of Chinese Urban and Rural Consumers. Journal of Consumer Marketing, Vol. 21, No. 4. p. 249-251. Emerald Group Publishing Limited.

17. Suprayitno, Eko. 2005. Ekonomi Islam: Pendekatan Ekonomi Makro Islam dan Konvensional. Penerbit Graha IImu, Jakarta. 